傾斜内壁をもつシャープターン往復流路内の乱流熱(物質)伝達*

\author{
中山 浩*1, 廣田真 史 $^{* 1}$, 藤田秀臣*2 \\ 奥田琢也*3, 小野靖 洋*3
}

\title{
Local Heat (mass) Transfer and Flow Characteristics in Serpentine Channels with an Inclined Partition Wall
}

\author{
Hiroshi NAKAYAMA*4, Masafumi HIROTA, Hideomi FUJITA, \\ Takuya OKUDA and Yasuhiro ONO

\footnotetext{
${ }^{* 4}$ Department of Mechanical Engineering, Nagoya University,

Furo-cho, Chikusa-ku, Nagoya-shi, Aichi, 464-8603 Japan
}

\begin{abstract}
Flow and heat/mass transfer characteristics for turbulent flow in serpentine channels with an inclined partition wall have been examined experimentally. Detailed velocity distributions have been measured using Particle Image Velocimetry for three kinds of partition wall's inclination angle with respect to the outer walls $\left(\alpha=+4^{\circ}, 0^{\circ},-4^{\circ}\right)$ at Reynolds number of $3.5 \times 10^{4}$. The PIV measurements results were compared with the published local mass transfer results for these three cases, and the mechanism of the heat (mass) transfer from the channel wall after turn section were discussed. Based on these data, the inclination angle can bring significant changes to the fluid characteristics and local heat (mess) transfer characteristics. The heat (mass) transfer enhancement after turn is controlled by the value of secondary flow velocity, convective mean velocity, turbulent kinetic energy, and their contribution rates are remarkably changed by the channel configurations.
\end{abstract}

Key Words: Forced Convection, Heat Exchanger, Naphthalene Sublimation Method, PIV

\section{1. 緹}

急激な曲がり部をもつ矩形断面の往復流路（シャー プターン流路）は各種熱交換器やカスタービン翼の内 部冷却流路において多く使用されている(1).このような 流路においては, ターン通過時に作用する遠心力に起 因した二次流れと，ターン下流における大規模な流れ のはく離・再付着とが共存するため, 流路内の流動は強 い三次元性を示し, 流路内の熱伝達特性も極めて複雑 な様相を示すことが知られている.

こうした往復流路内の強制対流熱伝達に関しては, 工業的な重要性のみならず工学的にも興味深いため, これまで熱電対 ${ }^{(2)}$, ナフタレン昇華法(3), 非定常感温液 晶法(4)などを用いた実臨, 数值解析(5)により, その特性 が明らかにされてきた. 著者らは, とくに流路隔壁を外 壁に対して傾斜させた場合について実験を行ってきて おり, 隔壁の傾斜に伴う主流や二次流れの局所的な加 減速，はく離領域の大きさの変化などにより流路の伝 熱特性は影著に変化し，適切な傾斜角度を選ぶことに よって流路の総合的な伝熱性能を向上させ得ることを 見出してきた ${ }^{(6)}$.

\footnotetext{
* 原稿受付 2003 年 12 月 19 日.

*1 正員, 名古屋大学大学院工学研究科 (- $464-8603$ 名古屋千 種区不老町).

*2 正員, 名城大学理工学部 (画 468-8502 名古屋市天白区塩釜口 1-501).

*3 トヨ夕自動車(株) (画 471-8571 豊田市卜ヨ夕町 1)。

E-mail : naka@mech.nagoya-u.ac.jp
}

一方ここした複雑な流路における伝熱機構を明ら かにするためには，伀熱特性と密接に関係する流動特 性を的確に把㩧することが不可欠である. しかし, 上記 のように流路内の流動特性と伝熱機構は複雑であるた め,その詳細については未だ不明な点が多い. 著者らは これまで, 伝熱のメカニズムを把握する第一段階とし て, 伝熱計測にナフタレン昇華法, 速度計測にPIV を用 いて傾斜内壁をもつ往復流路内の局所伝熱特性と平均 速度分布を明らかにし, 両者の比較・㭘㙒から, 局所伝 熟特性がその平均速度場の特性と概ね対応することを 示してきた(7).しかし,とくにターン下流部においては, 低速度領域においても高シャウド数を提示するなど, 伝熱特性と平均的速度場の間に必ずしも相関が認めら れない領域も存在することも指摘した.

そこで本研究では, 傾斜内壁をもつ矩形断面往復流 路内の乱流場についてより詳細な流動計測を行い, 前 報(7では明確になされなかった暨面近傍の速度分布, 主 流速度や変動速度強度の三次元分布などを明らかにす るとともに,こうした流動特性諸量と局所熱 (物質) 伝 達率との相関を求めることにより, 流路内の熱伝達を 支配するメカニズムについて検討を加えることを目的 とする.
2. 纪号
$A$ : 流路入口での長辺壁長さ $(=40 \mathrm{~mm})$ 
$A_{w}:$ 各流路断面における長辺壁長さ

$B:$ 短辺壁長さの半分 $(=10 \mathrm{~mm})$

$C:$ ターン間隙 $(=40 \mathrm{~mm})$

$d_{h}:$ 流路入口での水力直径 $(=26.6 \mathrm{~mm})$

$k_{x y}: x-y$ 平面内二次元乱れエネルギ $=\left(\left(\overline{u^{2}}+\overline{v^{2}}\right) / 2\right) / U_{b}^{2}$

$k_{y z}: y-z$ 平面内二次元乱れエネルギ $=\left(\left(\overline{v^{2}}+\bar{w}^{2}\right) / 2\right) / U_{b}^{2}$

$k_{x z}: x-z$ 平面内二次元乱れエネルギ $=\left(\left(\overline{u^{2}}+\overline{w^{2}}\right) / 2\right) / U_{b}^{2}$

$R e:$ レイノルズ数 $\left(=U_{b} d_{h} / v, v\right.$ : 空気の動粘度 $)$

$T_{d}$ 流路隔壁厚さ $(=8 \mathrm{~mm})$

$U, V, W:$ 各軸方向の平均速度

$u, v, w$ : 各軸方向の変動速度

$U_{b}$ : 流路入口における断面内平均速度

$X, Y, Z$ : 座標軸（図2参照）

$Y^{\prime}$ : 各流路断面における座標軸（図3 参照)

$X^{*}=X / d_{h} \quad\left(-9.1<X^{*}<1.5\right)$

$Y^{*}=Y /(A+T / 2) \quad\left(-1<Y^{* *}<1\right)$

$Y^{* *}=Y^{\prime} / A_{w} \quad\left(0<Y^{*}<1\right.$, ターン下流側直線部 $)$

$Z^{*}=Z / B \quad\left(-1<Z^{*}<1\right)$

$\alpha$ : 隔壁傾斜角度 $\left(=-4^{\circ}, 0^{\circ},+4^{\circ}\right.$; 図 2 参照)

\section{3. 実験装置および実験方法}

図1に実験装置の構成図を示す. 装置は既報(7)で用い たものと同様であり, 対象とする流路は, 流路入口にお ける断面が $40 \mathrm{~mm} \times 20 \mathrm{~mm}$ (断面アスペクト比 2 , 水力 直径 $d_{h}=26.6 \mathrm{~mm}$ ）のシャープターンをもつ往復流路で ある. 流路は吸い込み型で, 作動流体としての室温空気 は整流室, 測定流路, フィル夕室, 流量計を経て屋外に 排出される. 図 2 に流路の詳細および各壁面の名称を示 す. 測定流路の全壁面は透明アクリル板で製作されて おり, 短辺壁を場所に応じて, ターン上流外壁, 同隔壁 (内壁), 端面, ターン下流隔壁, 同外壁と呼ぶ. 隔壁先 端部から端面までの距離 (ターン間隙) は流路入口にお ける長辺壁の辺長と等しい $40 \mathrm{~mm} ゙$ あり, 隔壁の厚さは $8 \mathrm{~mm}$ である. 流路外壁に対する隔壁の傾斜角度 $\alpha$ を $+4^{\circ}, 0^{\circ},-4^{\circ}$ の 3 通りに変化させ 力直径を代表寸法としたレイノルズ数 $R e$ を $3.5 \times 10^{4}$ (断 面平均速度 $U_{b}=19.8 \mathrm{~m} / \mathrm{s}$ ) 一定として実験を行った. 以 下では, $\alpha=-4^{\circ}$ の流路を縮小流路, $\alpha=+4^{\circ}$ を拡大流路, $\alpha=0^{\circ}$ を平行流路と呼ぷことにする. 図2 と図3は縮小 流路を示している. 座標系の原点は平行流路の隔壁先 端の中心位置とし, 図2のように流路軸方向を $X$, 長辺 壁スパン方向を $Y$, 短辺壁スパン方向を $Z$ と定義した. $Z$ $=0$ の面は流路の二等分面に対応している.

本研究では, 特にターン内とその下流における流動 特性を調べるために, $X^{*} \geq-4.5$ の範囲において, $X-Y$ 平面 内の 6 断面 $\left(Z^{*}=0,0.2,0.4,0.6,0.8,0.9\right)$, 流路軸に

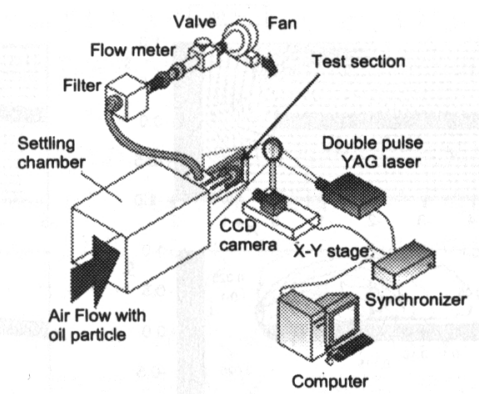

Fig.1 Experimental apparatus

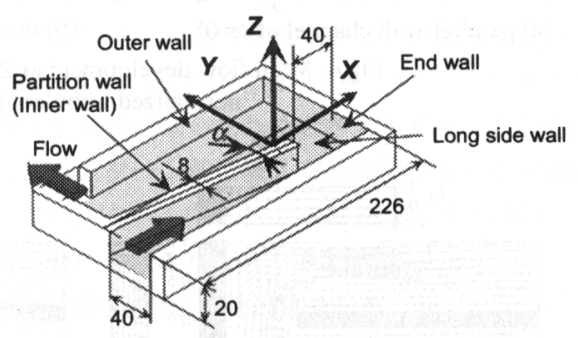

Fig.2 Details of test section

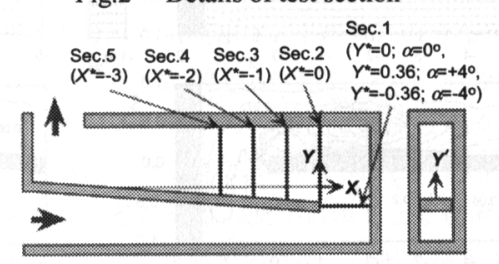

Fig.3 Locations of measuring cross-sections

対し垂直な $Y-Z$ 平面内の 9 断面 $\left(X^{*}=0,-0.5,-1.0,-1.5\right.$, $2.0,-2.5,-3.0,-3.5,-4.0)$ とターン間隙部断面で計測を 行った. なお本報においては紙面の都合上, 主に図3に 示すような 5 断面（Section 1～5）における結果につい て示す. また, これらの測定断面において二次流れ速度 分布は流路対称面 $\left(Z^{*}=0\right)$ に対して良好な対称性を示 したため, $1 / 2$ 断面 $\left(0<\left|Z^{*}\right|<1\right)$ での結果を示す.

平均速度と乱流強度の測定にはPIVを用いた. PIVの 構成は既報(7) と同じで, ダブルパルス YAGレーザ（出 力 : $15 \mathrm{~mJ}$, シート厚さ: $1 \mathrm{~mm}$ ) を可視化光源とし, 精密 $X-Y$ ステージ上に設置された CCD カメラ（KODAK ES1.0, 1008x1012pixels, 8bit) とレーザを同期させるシン クロナイザ (TSI製) およびコンピュータから構成され る.トレーサにはラスキンノズルから発生させたオイ ルの微小粒子（粒径 $1 \sim 5 \mu \mathrm{m}$ ）を用い, 2 枚の画像を取 得する際のパルス間隔は粒子移動量に応じて $5 \mu \mathrm{s} \sim$ $20 \mu \mathrm{s}$ の間で変化させた. 空間解像度の低下を防ぐため, 観察領域は $100 \times 100 \mathrm{~mm}^{2}$ を超えないように設定し, 濃度 相関法を用いて速度ベクトルを算出した. また測定精 度の向上を図るため, サブピクセル補間を行った ${ }^{(8)}$. 統 計量の算出には 1000 枚（500組）の粒子画像を用いた. 


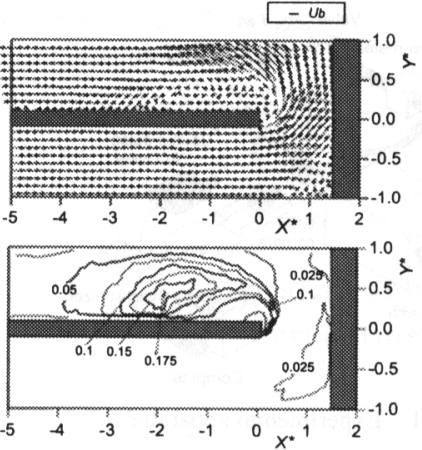

(a) parallel-wall channel of $\alpha=0^{\circ}$

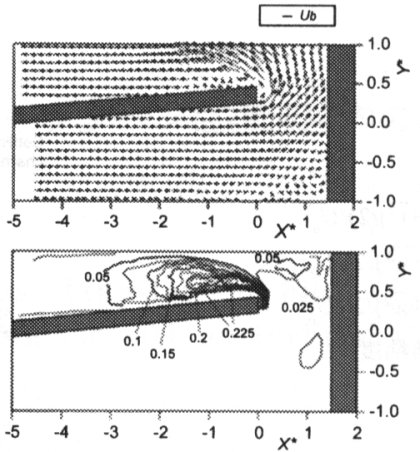

(b) divergent channel of $\alpha=+4^{\circ}$

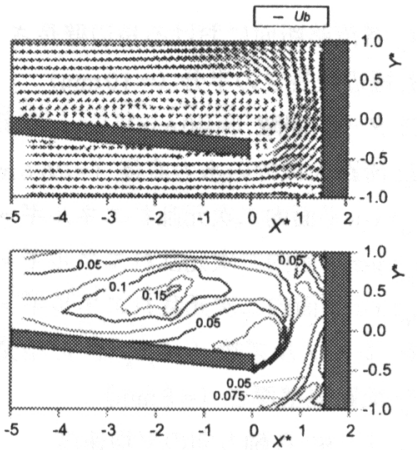

(c) convergent channel of $\alpha=-4^{\circ}$

Fig.4 Main flow development at $Z^{*}=0$ plane; mean flow vector distributions (upper figure), normalized turbulent kinetic energy $k_{x y}$ distributions (lower figure)

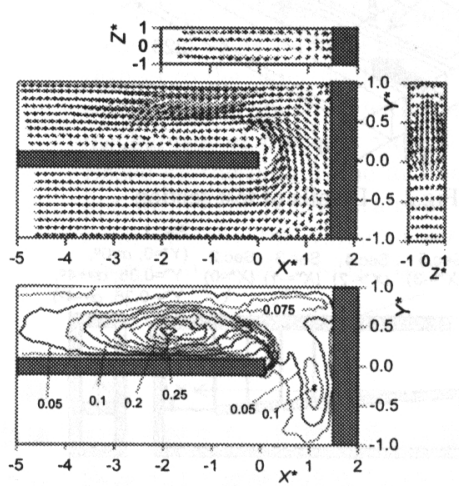

(a) parallel-wall channel of $\alpha=0^{\circ}$

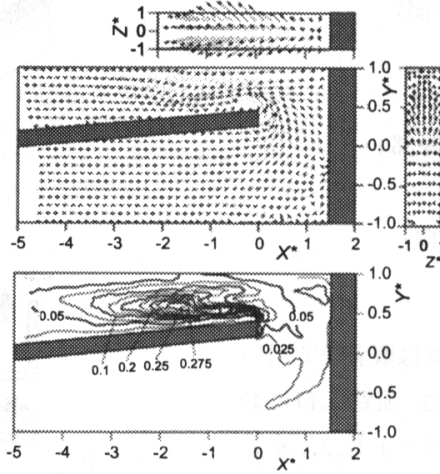

(b) divergent channel of $\alpha=+4^{\circ}$

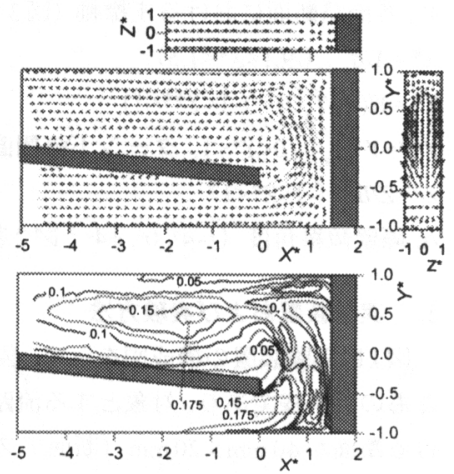

(c) convergent channel of $\alpha=-4^{\circ}$

Fig.5 Main flow development at $1 \mathrm{~mm}$ away from walls; mean flow vector distributions (upper figure), normalized turbulent kinetic energy $k_{x y}$ distributions (lower figure)

\section{4. 実験結果および考察 \\ 4. 1 速度場の概要}

\section{1.1 流路対称面の流動 流路内の流動特性の概要を}

把握するため, 図 $4(\mathrm{a}) \sim(\mathrm{c})$ にそれぞれ $\alpha=0^{\circ},+4^{\circ},-4^{\circ}$ の流路対称面内 $\left(Z^{*}=0\right)$ における平均速度ベクトル分 布と, 同平面内における二次元乱れエネルギ(9) $k_{x y}=$ $\left(\left(\overline{\left.u^{2}+\bar{v}^{2}\right) / 2}\right) / U_{b}^{2}\right.$ の分布を示す．まず，速度べクトルに注 目すると, いずれの流路においてもターン部に入った 流体は, 端面に衝突して減速すると同時にYの正方向へ 向きを変えられ, ターン下流の外壁に再衝突すること がわかる. 拡大流路では, 断面積の増加による減速のた めに端面に衝突する流れは縮小流路に比べて弱く, 隔 壁の先端部で流れが加速される傾向が見られる. 一方, 縮小流路ではターン部に流入する流体の流速が大きい ため, 端面側に高速流体が偏り端面および下流側外壁 に衝突する流れは強くなる. また, 後に示す端面近傍の 速度分布（図5）に見られるように, 端面壁の衝突位置 は上流側に移動する。端面に衝突した流れの一部は
ターン前半のコーナーに向かって逆流し, 循環領域を 形成する. この循環領域は $\alpha=+4^{\circ}, 0^{\circ},-4^{\circ}$ の順に小 さくなる.下流側のコーナー部には,このような顕著な 循環領域は観察されない.

ターン下流の領域では, いずれの流路でも隔壁先端 の上流側エッジで流れははく離し，隔壁に沿ってはく 離泡が形成される. 平行流路の場合,はく離した流れは $X^{*}=-2.6$ 付近の隔壁上に再付着する. 拡大流路では, は く離泡は他の流路に比べて小さいが, 隔壁の傾斜によ る流路断面積の減少により, この領域を通過する最大 流速は外壁側で $2.5 U_{b}$ に達する。縮小流路の場合にはは く離泡が大きく発達するため, 実質的な流路断面の狭 さくにより, 拡大流路と同様に, 外壁側に最大速度が約 $2.3 U_{b}$ の高速度領域をもつ $Y$ 方向に偏った速度分布が出 現する.こうした隔壁傾斜角度による主流の変化に対 応して, 時間平均的な再付着点は, 拡大流路の場合は $X^{*}=-1.2$, 縮小流路では $X^{*}=-4.8$ となる. はく離泡下流の 流れにも $\alpha$ の影響が現れ, 拡大流路では測定領域の出 
口付近で $Y$ 方向にほほ一様な速度分布へ回復するのに対 し，縮小流路では高速領域が外壁側に偏った速度分布 が測定領域出口まで維持される.

$k_{x y}$ 分布は平均速度場に対応して, 全般に速度勾配の 急な領域で大きくなる傾向が見られる.ターン部にお いては，上流側コーナー部における循睘領域とその外 側を流れる主流との間に形成される速度せん断層で, 比較的強い速度乱れが生成されている．この $k_{x y}$ の極大 值は, 加速された流れがターン部に流入する縮小流路 でより顥著となる.

ターン下流の $k_{x y}$ は, はく離泡に治ったせん断層を中 心として高い值を示している. 平行流路における $k_{x y}$ の 最大值は再付着点 $\left(X^{*}=-2.6\right)$ の近傍で観察されること から,この領域の強い乱れは, せん断層における速度こ う配により生成される速度乱れに，再付着流の非定常 性が重量することにより生じていると考えられる．再 付着点の下流では, はく離泡の消失により乱れの生成 が減少するため, $k_{x y}$ の值も速やかに減少している. 拡 大流路の場合には, $X^{*}=-1$ 付近に $k_{x y}$ の極大值が現れる が, 平行流路と同様に, はく離泡の下流において速度変 動は急激に減衰している.それに対し, はく離泡が下流 まで大きく発達する縮小流路では, 測定領域の出口付 近においても $k_{x y}$ は比較的高い值を示している. また, こ の流路における $k_{x y}$ は再付着点 $\left(X^{*}=-4.8\right)$ よりかなり上 流で最大値に達していることより， $k_{x y}$ に及ぼす再付着 流の非定常性の影䇾は他の流路に比べて小さく，はく

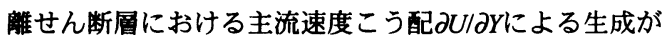
$k_{x y}$ の分布に対して支配的と推定される.

4. 1.2 壁面近傍の流呩 次に各流路の壁面近傍におけ る流動について示す. 図5(a)〜 (c) は各流路の壁面近傍 (長辺壁, 端面, ターン下流外壁からそれぞれ $1 \mathrm{~mm}$ 離れ た平面. すなわち $Z^{*}=-0.9, X^{*}=1.47, Y^{*}=0.98 ） に お ~$ ける平均速度べクトル, および長辺壁近傍の $k_{x y}$ 分布で ある. 長辺壁近傍の流動は, ターン部とその下流におい て流路対称面内 $\left(Z^{*}=0\right)$ の流動とやや異なる様相を示 している.ターン部に流入した流れは， $Z^{*}=0$ と同様に いずれの流路においても隔壁先端ではく離するが, $Z^{*}=0$ ではターン間隙付近で端面に向かう流れが観察さ れたのに対し，長辺壁近傍では逆に隔壁側へ向かう流 れが支配的である.これは次節で述べる二次流れのパ ターンと対応している. ターン下流部では, $Z^{*}=0$ での 流れと同様に隔壁に治ってはく離泡が形成されるが, はく離泡の外側では外壁側から隔壁側へと向かう流れ が強くなり，その速度は $\alpha$ を負から正（縮小流路から拡 大流路）に変化させるにつれて大きくなる.こうした流 れの影響を受け, はく離泡はY方向に押しつぶされたよ
うにやや扁平な形状を示す. また, 測定領域出口で観察 される高速領域の外壁側への偏りは, $Z^{*}=0$ の場合に比 ベて若干大きくなっている.

$k_{x y}$ は, いずれの流路においても $Z^{*}=0$ に比較して全般 に高い値を示し, 乱れの強い領域がより下流にまで及 んでいる.これは, $\partial U / \partial Y に$ 加えて, 長辺壁の影響によ り $\partial U / \partial Z$ も大きくなっているためと考えられる. とく に, 平行流路と縮小流路の場合には, ターン内において $k_{x y}$ の顕著な増加が認められる.これは, 端面あるいは 下流側外壁に衝突した流れが長辺壁に再度衝突し, さ らにその流れが上流側に逆流することにより上記の速 度こう配に加えて $\partial U / \partial X や \partial V / \partial Y$ も大きくなり, 乱れの 生成がより活発になったためと考えられる.これらの 流路に比べてターン部に流入する速度が低い拡大流路 の場合には, ターン内における $k_{x y}$ の増大も小さい.

\section{2 流路軸に垂黾な断面内の流勒特性}

4. 2.1 主流および二次流れ速度分布 図6(a) (c)にそ れぞれ $\alpha=0^{\circ},+4^{\circ},-4^{\circ}$ の条件における二次流れ速度べ クトル (上半分) と主流速度 (下半分) の分布を示す. 各図の最上部に示した図 (Sec.1) は, ターン間隙部の断 面に対応している.これらの図では順流と逆流を理解 しやすくするため, Sec.1では $V / U_{b}$, Sec.2以降では-U/U の分布を示し，それぞれの值が負値をとる逆流領域は 灰色で示した. 図の左側が隔壁側, 右側は端面(Sec.1),

外壁側（Sec.2 5）に対応する.

まず平行流路について検討する. 図 6(a) に示すよう に, Sec.1 $\left(Y^{*}=0\right)$ では, ターン上流の直線部からター ン部へ入った流れの影翠により, 隔壁側から端面に向 かう強い流れが生じている.この流れは端面に衝突し た後に長辺壁に再衝突し, 長辺壁に沿って隔壁側へ向 かう絴渦を形成する. Sec.2 ( $\left.X^{*}=0\right)$ では, 外壁側に遠 心力に起因した絴渦 ${ }^{(10)}$ が明確に観察される.この二次 流れが，外壁側に偏っている高速の流体を長辺壁に 治って隔壁側へと輸送するため, 主流速度は断面中央 部よりも長辺壁近傍で高くなる特異な分布を示す.

下流方向に進むと，外壁側に向かう流れは徐々に弱 まり, 流れの再付着に伴って隔壁側に向かう流れが強 くなる.この二次流れの影響により，はく離泡は $X^{*}=0$ のY軸付近で外壁側に膨らむ凸形状をとっていたのに対 し，下流に向かうにつれて徐々に押しつぶされ，Sec.4 では凹形の断面形状に変化する. Sec.5 $\left(X^{*}=-3\right)$ では逆 流領域は消滅し,外壁側に明瞭な縦渦は見られず, 二次 流れ自身も弱くなる.なお,これらの平行流路における 流動の特徵は, 同型の流路に対して行われたLDVによ る実験結果 ${ }^{(11)}$ とよく一致しており, 本手法の有効性が 確認できる. 


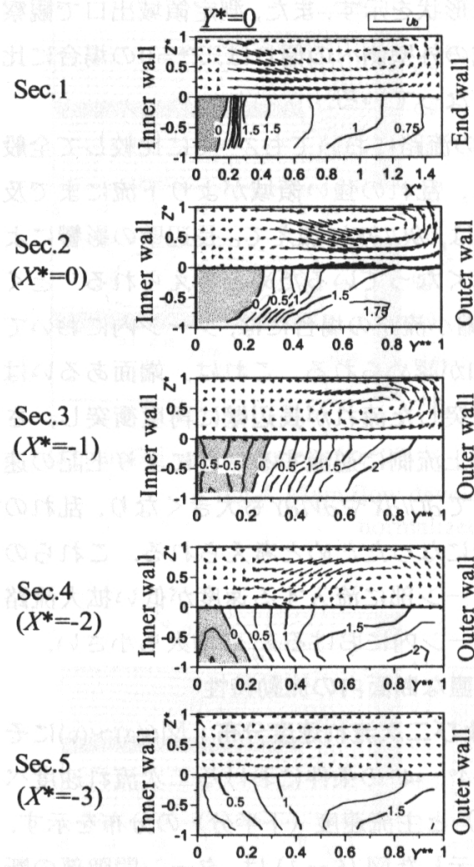

(a) parallel-wall channel of $\alpha=0^{\circ}$
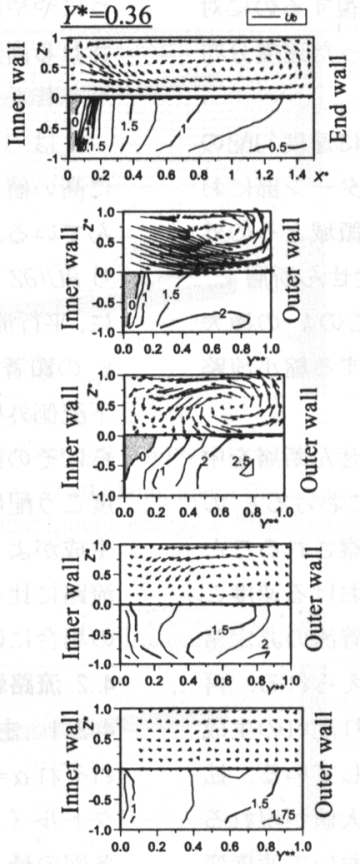

(b) divergent channel of $\alpha=+4^{\circ}$
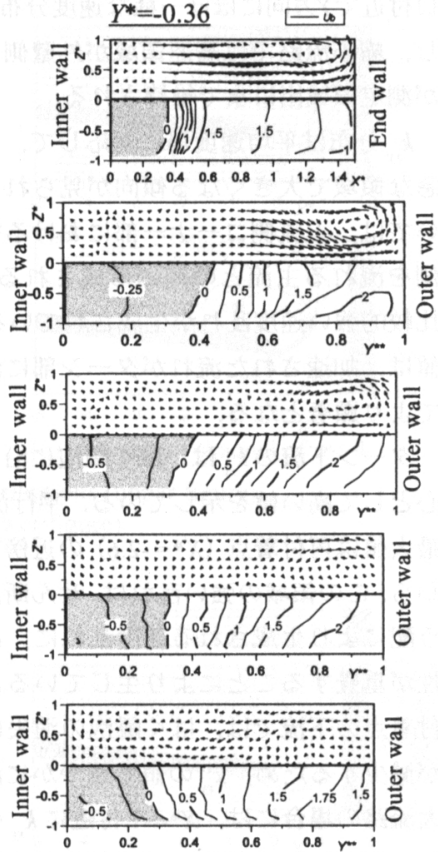

(c) convergent channel of $\alpha=-4^{\circ}$

Fig.6 Secondary flow vectors (upper figure) and contour plots of normalized axial velocity $-U / U_{b}\left[V / U_{b}\right.$ for Sec.1] (lower figure)

隔壁を傾斜させた場合, S e c . 1 のターン間隙部 $\left(Y^{*}=0.36,-0.36\right)$ では, ターン部に流入する主流速度の 高低に対応して, 縮小流路 (Fig.6(c)) では強い二次流 れが観察されるのに対し，拡大流路（Fig.6(b)）の二次 流れは他の流路に比べて幾分弱くなっている. ターン 出口断面（Sec.2, $X^{*}=0$ ） では, 拡大流路の外壁側に向 かう二次流れ速度が増加し縦渦も強まっている.これ は, 図4(b)に見られるように, ターン間隙通過時に隔壁 のすぐ外側で最大速度に達する”主流”速度 $V$ が, Sec.2 では二次流れ速度として検出されるためである. 一方, 縮小流路では流路断面の半分近くをはく離泡が占める ため, 縦渦のスケールはSec.1に比べて小さくなる.

Sec.3, Sec.4では, どちらの流路においても外壁側に 向かう流れが弱まり, 隔壁側に向かう流れが強くなる 傾向が認められる. 拡大流路の場合, はく離泡はSec.4 以降で消滅し, Sec.5 では二次流れは弱くなり明確な縦 渦は観察されなくなる.一方, 縮小流路では, Sec.5に おいても大規模な逆流領域が存在し, 流路断面中央部 には隔壁側に向かう流れが観察されるが, 他の流路と 同様に外壁側の縦渦は消滅する. なお, 縮小流路におけ るはく離泡の断面形状が, 下流に向かうにつれて凸型か ら凹型に変化する点は, 平行流路と同様の傾向である.

4. 2.2 乱れエネルギ分布 図7(a)〜 (c) に, 図6に示し た各断面の二次流れ速度に対応する二次元乱れエネル
ギ ${ }^{(9)} k_{y z}$ (ただし Sec.1 では $k_{x z}$ ) の等値線分布を示す.ま ず基本となる平行流路の場合について検討する.ター ン間隙部 (Sec.1) とターン出口部 (Sec.2) において, $k_{y z}$ は長辺壁に近い位置で極大值を示している.この領域 は図6(a)で縦渦が存在していた位置に対応しており, 長 辺壁に沿って外壁 (端面) 側に向かう流れと, 逆に隔壁 側に向かう流れとが衝突することにより, Sec.1では $u^{\prime}$, $\operatorname{Sec} .2$ ではv'の生成が大きくなっていると考えられる. また, Sec.2では隔壁側のはく離せん断層付近 ( $Y^{* * \sim 0.4) ~}$ にも高 $k_{\mathrm{yz}}$ 領域が認められる.これは, U/U 6(a)）において等值線間隔が密な領域と対応しており, 図4(a)と5(a)からも推察されるように主にはく離せん断 層で生成される $u$ 'からの再分配に起因すると考えられ る. Sec.3においても, 縦渦に対応する位置とはく離せ ん断層付近で $k_{y z}$ は高い値を示している. とくに, 後者 の $k_{y z}$ はSec.2よりも増加するとともに, 断面内のより広 い領域で高い値を示している.

Sec.4とSec. 5 では, 縦渦の消滅に伴い外壁側の高 $k_{y z}$ 領 域は消滅し，せん断層付近の高 $k_{y z}$ 領域が支配的となる が, その值は下流方向にわずかに減少しながら隔壁側 に移動する. 図6の二次流れの分布からもわかるよう に, Sec.5 では断面内の平均速度 $(V, W)$ が小さい $\left(U_{b}\right.$ の $20 \%$ 程度) にもかかわらず, 隔壁側の $k_{y z}$ はSec.4まで と同レベルの高い值を維持している. このことは,この 
Sec. 1

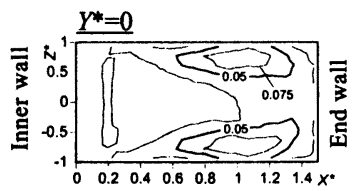

Sec. 2 $\left(X^{*}=0\right)$

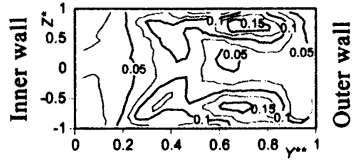

Sec.3 $\left(X^{*}=-1\right)$

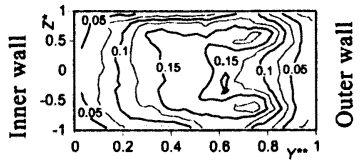

Sec. 4 $\left(X^{*}=-2\right)$

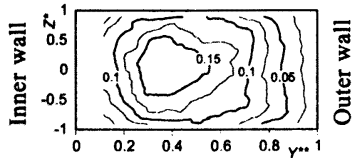

Sec. 5 $\left(X^{*}=-3\right)$

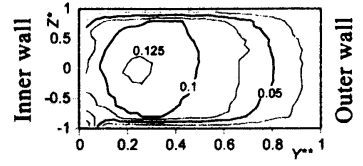

(a) parallel-wall channel of $\alpha=0^{\circ}$
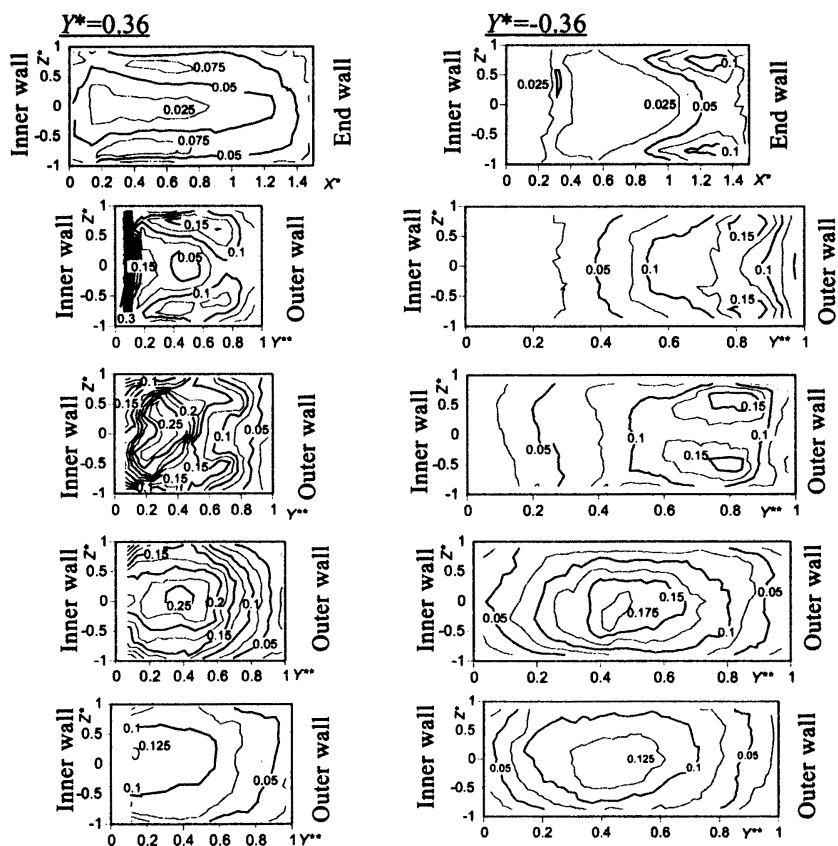

(b) divergent channel of $\alpha=+4^{\circ}$
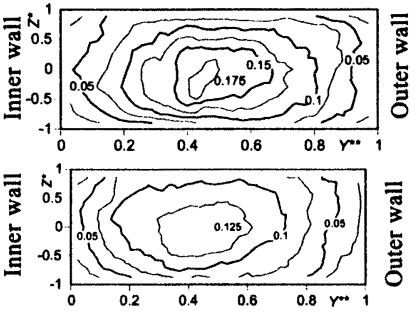

(c) convergent channel of $\alpha=-4^{\circ}$

Fig.7 Contour plots of normalized two-dimensional turbulent kinetic energy distributions $k_{y z}$ [ $k_{x z}$ for Sec.1]

領域において流れは大規模な非定常性を有することを 示唆するものである.

隔壁傾斜角度を変えた場合, ターン間隙部 (Sec.1)の $k_{x z}$ は平行流路と同様に長辺壁近傍で極大值をとるが, この高 $k_{x z}$ 領域は拡大流路の場合は隔壁側へ，縮小流路 の場合は端面側へ偏る傾向を示す.これは, 平行流路の 場合と同様に, 図6において絴渦の現れた位圈と対応し ている.Sec.2とSec.3では, 二次流れによる絴渦が観察 された長辺壁近傍において $\boldsymbol{k}_{y z}$ が極大值をとる傾向には 変わりがないが，隔壁側に隔壁傾斜角度の違いが影著 に現れる.すなわち, 拡大流路の場合には隔壁近傍には く離せん断層に対応した高 $k_{y z}$ 領域が見られるのに対し て, 縮小流路にはそのような領域は锶察されない.これ は, 拡大流路の場合, 流路断面積の娍少による流れの加 速のために平均速度勾配 $\partial U / \partial Y や \partial V / \partial Y$ が縮小流路に比 べて大きくなり，乱れの生成が活発になることに起因 すると考えられる。

Sec. 4 とSec. 5 においては, 長辺壁近傍の高 $k_{y z}$ 領域は消 减し，いずれの流路でも $k_{y z}$ ははく離せん断首付近のみ で極大值をとるようになる. 払大流路ではSec.4以降で はく離泡が消减し，せん断による乱れの生成が弱くな るため, Sec.4と 5 の間で $k_{y z}$ は著しく減衰している. 一 方, はく離泡が下流まで発達する縮小流路では, Sec.5
においても広い領域にわたって $k_{y z}$ は比較的高い値を維 持している.

4. 3 ターン部周辺における流功と伝熟の相的 前報(6)で は, 各流路で測定した局所シャウド数分布の比較から, 熱伝達に及ぼす隔壁傾斜角度の影響はターンの内部か らその下流部にかけて顕著に現れることを示した．こ こでは, 前報で示した局所シャウド数分布を再提示し， 本計測によって得られた壁面近傍の平均速度や変動速 度分布と局所シャウド数との相関を求めることにより, ターン部周辺における熱伝達を支配する流れについて 検討する. なお, 紙数の制限上, ここでは最も広い面積 を占める長辺壁上のターン下流部 $\left(X^{*}<0\right)$ のみについて 考える。

図 8(a)〜 (c) は各流路における長辺壁上の局所シャウ ド $S h$ 数の分布 ${ }^{(6)}$ である. 図中の数値は, $S h$ を円管内の 完全発達乱流に対する平均シャウド数 ${ }^{(12)} S h_{0}$ で除した値 を示しており, $S h / S h_{0}$ の值が高いほど白く表示されてい る. ターン内から下流に至る領域で, いずれの流路にお いても複雑な $S h$ 分布が観察される.

一般に, 壁面からの熱伝達に対しては, 壁に垂直な速 度成分が最も大きく寄与すると考えられるが，複雑な 流動の場合には壁面に平行な成分の寄与も重要になる 可能性がある ${ }^{(10)}$. そこで本研究では, 各速度成分が長 
(a) parallel-wall channel

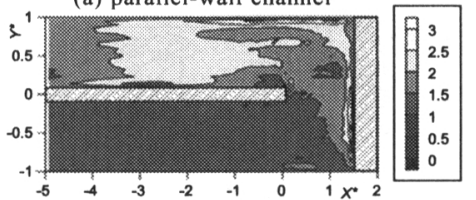

(b) divergent channel

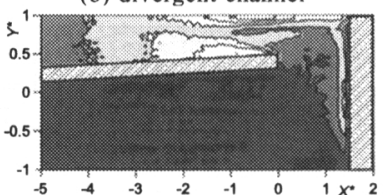

(c) convergent channel

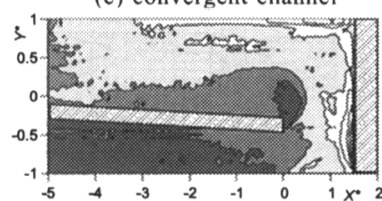

Fig.8 Distribution maps of local Sherwood numbers $\left(S h / S h_{0}\right)^{(3)}$
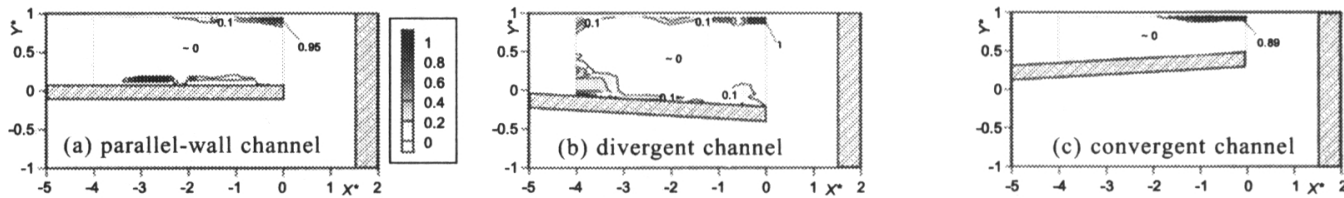

Fig.9 Heat(mass)-fluid correlations distributions between vertical velocity $\sqrt{W^{2}}$ at $Z^{*}=0.9$ and $S h$
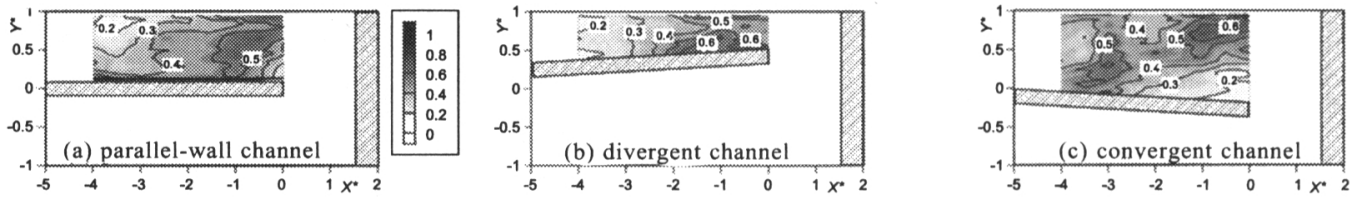

Fig.10 Heat(mass)-fluid correlations distributions between vertical velocity $\overline{w^{2}}$ at $Z^{*}=0.9$ and $S h$
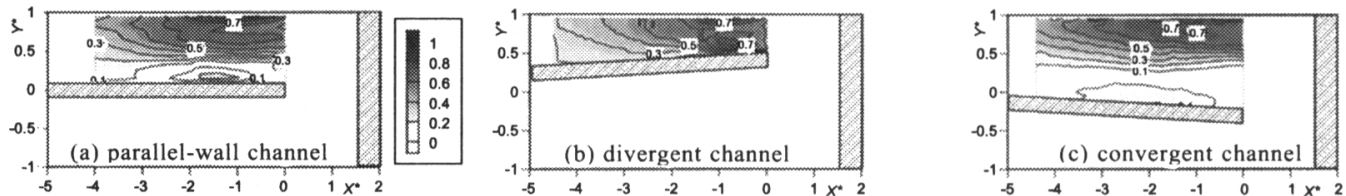

Fig. 11 Heat(mass)-fluid correlations distributions between surface velocity $\left(U^{2}+V^{2}\right)^{0.5}$ at $Z^{*}=0.9$ and $S h$
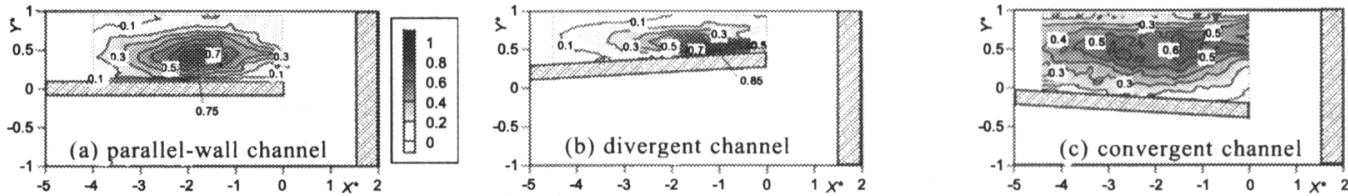

Fig.12 Heat(mass)-fluid correlations distributions between two-dimensional turublent energy $k_{x y}$ at $Z^{*}=0.9$ and $S h$

辺壁からの熱 (物質) 輸送に及ぼす影響を明らかにする ために, 長辺壁近傍である $Z^{*}=-0.9$ の平面で測定した壁 面に垂直な速度成分 $\left(W^{2}\right)^{1 / 2}$ と $\bar{w}^{2}$ ，および壁面に平行な 速度成分 $\left(U^{2}+V^{2}\right)^{1 / 2}$ と $\left.k_{x y}=\left(\left(\overline{u^{2}}+\overline{v^{2}}\right) / 2\right) / U_{b}^{2}\right)$ に注目し, Son らにより提案された方法 ${ }^{(9)} に$ 基づき次式で各速度成分 と局所シャウド数との間の相関を定義する.

$$
\begin{aligned}
& \left(\sqrt{W^{2}} /\left(\sqrt{W^{2}}\right)_{\max }\right)\left(S h / S h_{\max }\right) \\
& \left(\overline{w^{2}} / \overline{w^{2}} \max _{\max }\right)\left(S h / S h_{\max }\right) \\
& \left(\sqrt{U^{2}+V^{2}} /\left(\sqrt{U^{2}+V^{2}}\right)_{\max }\right)\left(S h / S h_{\max }\right) \\
& \left(k_{x y} / k_{x y-\max }\right)\left(S h / S h_{\max }\right)
\end{aligned}
$$

ここで添字の $\max$ は考慮している領域内での最大值を 表している．局所シャウド数が高い位置で速度成分も 同様に大きくなれば, これらの式の值は 1 に近づく.し たがって, 各速度成分のうち上記の相関が1に近い成分
ほど，その領域の伝熱に大きく寄与していると見なす ことができる.

4. 3.1 平行流路 平行流路の夕ーン出口直後の領域 ($1<X^{*}<0 ）$ では, 外壁との接合部に沿って狭い高 $S h$ 領 域, 隔壁側にははく離泡に対応した低 $S h$ 領域が観察さ れる，外壁側の高 $S h$ 領域は，図 9(a)の $\left(W^{2}\right)^{1 / 2}$ と最も高 い相関があり, 図6(a)のSec.2に示した二次流れベクト ルからも明らかなように, ターン下流外壁に衝突した 流れが長辺壁に吹き下ろす効果によって伝熱が促進さ れていることが分かる.

はく離泡に対応する低 $S h$ 領域の下流 $\left(-3<X^{*}<-1\right)$ で は, $S h$ は全体的に $S h / S h_{0}>2$ の高い值を示す.この高 $S h$ 領域のうち外壁側では, 壁面に平行な平均速度成分 $\left(U^{2}+V^{2}\right)^{1 / 2}$ とShの相関が高い值を示し, 外壁側に偏った 高速流がこの領域の伝熱を促進していると考えられる. この傾向は, Sonらの結果 ${ }^{(9)}$ と定性的に一致する. 一方, 隔壁側では，図12(a)に見られるようにShは $k_{x y}$ と高い 
相関があり，はく離泡に起因したせん断層で生成され る強い乱れのうち, 壁面に平行な成分 $k_{x y}$ によって伝熱 が促進されている. 壁面に垂直な変動速度成分 $\overline{w^{2}}$ と $S h$ との相関はこの領域全体にわたって $0.3 \sim 0.45$ 程度であ り，伝熱に対する奇与は壁面に平行な速度成分ほどは 大きくないといえる.

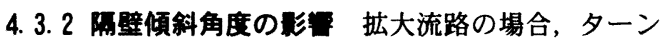
出口直後の外壁極近傍では，平行流路と同様に壁面に 垂直な平均速度成分 $\left(W^{2}\right)^{1 / 2}$ と $S h$ が高い相関を示してい る.一方，隔壁側にははく離泡に起因した低 $S h$ 領域は 出現せず, Shは隔壁に治った広い領域 $\left(-2.5<X^{*}<0\right)$ で 平行流路の対応領域よりも高い值を示している. この 高 $S h$ 領域では，図 10(b)〜 12(b)に見られるように $\left(U^{2}+V^{2}\right)^{1 / 2}, \overline{w^{2}}$ および $k_{x}$ がともにSh と高い相関を示して おり，流路断面積の減少による流れの加速にはく離せ ん断層における強い乱れの効果が重畳されて, 伝熱が 促進されていると考えられる.

縮小流路の場合には，図4(c)に示したように隔壁に 治ってはく雄泡が大きく発達するために，隔壁側の低 $S h$ 領域も他の流路に比べて広い面積を占めている. こ のはく離泡の外側（外壁側）では, Sh は平行流路のは く離泡下流領域と同程度の高い值を示しており，この 高 $S h$ 領域は測定部の出口（X*=-5）近傍まで維持され ている. 図11に示した $\left(U^{2}+V^{2}\right)^{1 / 2}$ とShの相関は,この高 $S h$ 領域のうち外壁近傍で高い值を示しており，はく離 泡の存在により外壁側に偏った高速流の伝熱促進効果 が認められる.一方, はく離泡に近い領域では変動速度 による伝熱促進効果が顕著であるが, $\overline{w^{2}}$ の奇与は $k_{x y}$ に 比べて幾分小さくなっている．このような縮小流路の 高 Sh 項域における伝熱促進のメカニズムは, 上に述べ た平行流路と類似である.

\section{5. 站}

本研究ではPIVを用いて傾斜隔壁をもつ往復流路内 乱流の流動計測を行い, 平均速度および乱流エネル ギーの三次元分布を明らかにした．また同型の流路系 で得られた局所シャウド数分布と各速度成分との相関 を求めることにより，流路内の熱伝達のメカニズムに ついても検討した，以下に本研究の主な結論を示す.

(1)いずれの流路においても流れは隔壁先端ではく離 し, その下流で隔壁上に再付着するため, ターン下流 側の隔壁上には三次元形状を持つはく離泡が形成さ れる. 扗大流路のはく離泡は平行流路に比べて著し く小さく, 縮小流路には逆に大規模なはく離泡が出 現する. 平行・縮小流路におけるはく離泡の外側（外 壁側）での主流は高速領域が外壁側に偏る傾向が強
くなる.

(2)ターン間隙部とターン下流部の断面内には遠心力に 起因する一対の縦渦が外壁側に形成される.この二 次流れは拡大流路で強くなり縮小流路では弱くなる. いずれの流路でも, 隔壁先端から $3 d$ 程度の短い距離 で, 明確な縦渦は消滅する.こうした二次流れの影響 を受け, ターン下流の主流は流路中心部よりも長辺 壁近傍で速度が高くなる特異な速度分布を示す。

(3) ターン下流部では, はく離泡とその外側の高速領域 との間のせん断層に治って強い乱れが生成される. 隔壁先端から下流方向に乱れの強い領域は断面内に 広がるが, 再付着点の下流では乱れは減衰する. 特に 拡大流路では $k_{x y}$ の最大値は他の流路に比較して高い が減衰も著しく, 測定流路出口部における值は他の 流路を下回る.

(4) ターン下流の高 $S h$ 領域 (長辺壁上)における伝熱は, 流路により異なった速度成分に支配される．平行流 路と縮小流路の場合, 高 $S h$ 領域のうち外壁側では壁 に平行な平均速度成分が支配的であるのに対し，隔 壁側では壁に平行な変動速度成分により伝熱が促進 される，壁に垂直な変動速度成分の寄与は比較的小 さい.一方, 扗大流路では上記の速度成分が何れもSh と高い相関を示し, 流れの加速にはく離せん断層に おける強い乱れの効果が重量して伝熱促進が生じる.

\section{考文献}

(1) Metzger, D.E., Sahm, M.K., Trans. ASME, J. of Heat Trans., 108, (1986), 500-506.

（2）望月貞成, 村田章, 柴田良輔, Wen-Jei Yang, 機論, 64-623, B(1998), 2216-2223.

(3) Hirota M., Fujita H., Syuhada A., Araki, S. Yoshida, T. and Tanaka, T., Int. J. Heat Mass Transfer, 42 (1999), 3757. 3770.

(4) Liou T-M., Chen C.-C., Tzeng, Y.-Y., Tsai T.-W., Int. J. Heat Mass Transfer, 43 (2000), 3233-3244.

(5) Jang, Y.-J., Chen, H-C., Han, J.-C., J. Heat Transfer, 123, (2001) 563-574

(6) 廣田真史, 藤田秀臣, 中山浩, 柳田真, 梶田明男, 機論, 67-656, B(2001), 1012-1019.

（7）廣田真史, 中山浩, 蔡藞, 藤田秀臣, 加藤達人, 倉 本博幸, 機論, 68-669, B(2002)，1523-1530。

(8) PIV ハンドブック, 可視化情報学会編, 森北出版

(9) Son, S.Y., Kihm, K.D., Han, J.-C., Int. J. Heat Mass Transfer, 45 (2002), 4809-4822.

(10) Liou T-M., Chen C.-C., Trans ASME, J. Turbomach., 121, (1999), 167-174.

(11) 中山浩, 廣田真史, 藤田秀臣, 山田武, 小出裕輔, 機論, 69-681, B(2003), 1171-1179.

(12) Bejan, A., Convective Heat Transfer, (1984), 326-327, Wiley, New York. 